J. Reprod. Fert. (1974) 41, 265-273

\title{
OVULATION AND EARLY EMBRYONIC DEVELOPMENT IN THE CAPTIVE VAMPIRE BAT, DESMODUS ROTUNDUS
}

\author{
F. QUINTERO H. AND J. J. RASWEILER IV*
}

Departamento de Morfologia, Division de Salud, Universidad del Valle, Cali, Colombia, and *International Center for Medical Research and Training, Cali, Colombia, and Department of Anatomy, College of Physicians and Surgeons of Columbia University, 630 West 168th Street, New York, N.Y. 10032, U.S.A.

\section{(Received 31st December 1973)}

\begin{abstract}
Summary. Ovarian function and early development of the embryo was investigated histologically in vampire bats removed at timed intervals after mating from a laboratory colony. Both ovaries were equally functional, but a single ovum only was released at each oestrus. The preovulatory follicle or new CL was in the opposite ovary from the old CL in most bats possessing old CL. Large preovulatory follicles were observed as late as Day 5 (Day 1 = first day of sperm-positive vaginal smears). Early cleavage stages were recorded on Days 3 to 8 . Advanced morulae and early blastocysts sometimes lacking zonae pellucidae were observed in the oviducts on Days 15 and 16.
\end{abstract}

\section{INTRODUCTION}

The sanguivorous vampire bat, Desmodus rotundus, is a serious animal pest in the New World tropics. Annual livestock losses due to vampire-transmitted rabies alone are extensive, and this bat is a demonstrated or potential vector for a number of other diseases. The wounds left on livestock by vampires may subsequently become infected and, if on the teats, may interfere with lactation (Greenhall, 1970, 1972; Constantine, 1970; Mackenzie, 1972; Correa-Giron, Calisher \& Baer, 1972).

While the undesirable aspects of the vampire bat's biology are well recognized, the possible usefulness of this species in biomedical research has not been fully explored. Recent studies have established that several of the American leafnosed bats (family Phyllostomatidae) exhibit advanced development of the embryo in the oviduct, a unilateral oviducal reaction, menstruation, and some possibly unique similarities to the higher primates in uterine biology during ovum implantation (Rasweiler, 1970, 1972, 1974; Bonilla \& Rasweiler, 1974). In view of the close phylogenetic relationship between the phyllostomatid bats and Desmodus (Forman, Baker \& Gerber, 1970), the latter species should be considered as a possible model in the further study of these phenomena.

Reprint requests to: Dr J. J. Rasweiler IV, Department of Anatomy, Gollege of Physicians and Surgeons of Columbia University, 630 West 168th Street, New York, N.Y. 10032, U.S.A. 
At present, our knowledge of reproduction in Desmodus is largely of a behavioural nature (Greenhall, 1965) or based on the study of reproductive tracts which were either collected in the field or not precisely timed (Wimsatt \& Trapido, 1952; Wimsatt, 1954; Björkman \& Wimsatt, 1968; Fleming, Hooper \& Wilson, 1972). An effort has been made in this investigation to obtain carefully timed data on ovulation and early embryonic development in vampire bats maintained in the laboratory.

\section{MATERIALS AND METHODS}

\section{Animal care and management}

The vampire bats were captured with hand nets in their diurnal roosts in the Western Andean Cordillera near Cali, Colombia. They were maintained in captivity on beef blood offered late each afternoon in shallow dishes. The blood was collected at an abattoir, treated with sodium citrate (at first, $10.7 \% \mathrm{v} / \mathrm{v}$ of $2.2 \%$ aqueous $\mathrm{Na}_{3} \mathrm{C}_{6} \mathrm{H}_{5} \mathrm{O}_{7} .2 \mathrm{H}_{2} \mathrm{O}$; later, $10.0 \% \mathrm{v} / \mathrm{v}$ of $3 \%$ aqueous $\mathrm{Na}_{3}-$ $\mathrm{C}_{6} \mathrm{H}_{5} \mathrm{O}_{7} \cdot 2 \mathrm{H}_{2} \mathrm{O}$ ) and frozen until the day of use (modified from Dickson \& Green, 1970). Initially, the bats were housed in sexually segregated groups in wood, wire and glass cages similar in design to those of Wimsatt, Guerriere \& Horst (1973). The animal room was illuminated by subdued natural light. Because of the proximity of the animal facilities to the equator $\left(3^{\circ} 26^{\prime} \mathrm{N}\right.$ latitude), the variation in daylength throughout the year was slight. After 4 to 8 months in captivity, the twenty-three young which had been born in the laboratory were removed (there had also been two abortions among the sixty-three females incorporated in this study), and one to three males were added to each group of eleven to fourteen adult females for breeding purposes. Because of the slow rate at which most of the females mated, new males were subsequently placed with the females in five of the six groups.

\section{Timing of reproductive stages}

Vaginal smears were taken each morning between 08.00 and 10.00 hours by means of micro-eyedroppers (Rasweiler, 1970, 1972). The reproductive tracts were timed from the first appearance of spermatozoa in the smears (= Day 1 post coitum). All bats were killed between 09.00 and 12.00 hours for histological examination.

\section{Histological procedures}

The reproductive tracts were fixed in Zenker's fluid or acetic acid-mercuric chloride-formalin (Lillie, 1965) for $8 \mathrm{hr}$, washed overnight in tap-water and processed through ethanol, cedar oil and benzene to paraffin wax. The tracts were serially sectioned at $7 \mu \mathrm{m}$ and stained with haematoxylin and a buffered Giemsa stain ( $\mathrm{pH} \mathrm{4.5;} \mathrm{Lillie,} \mathrm{1965),} \mathrm{Masson's} \mathrm{trichrome} \mathrm{procedure} \mathrm{or} \mathrm{the}$ periodic acid-Schiff (PAS) procedure. Some slides were placed in distilled water rather than periodic acid before being stained with Schiff's reagent.

\section{RESULTS}

\section{Breeding success}

Ten females were pregnant at the time of introduction of the males. Two 
aborted during the subsequent month, while the remaining eight successfully delivered their young. The young were removed between 4 and 71 days after birth. Daily examination of the maternal vaginal smears for spermatozoa from the day of birth indicated that no matings occurred while the young were still housed with their mothers. The time of natural weaning is not known. Spermatozoa first appeared in the smears of seven of the mothers between 29 and 117 days after the birth of, or from 15 to 73 days after removal of, the young. One female did not mate again.

Mating activity was initiated in the remaining bats according to the following pattern (expressed as number of females mating for the first time in captivity/month after first introduction of the males): $8 / 1,8 / 2,3 / 3,3 / 4,11 / 5$, $11 / 6,1 / 7,2 / 8,1 / 9,1 / 10$. In total, $89 \%$ (56 of 63 ) of the females placed with males eventually mated (Table 1 ). Those females which failed to mate were

Table 1. Breeding success in captive Desmodus rotundus

\begin{tabular}{l|c}
\hline \multicolumn{1}{c|}{ Reproductive condition } & No. of animals \\
\hline Failed to copulate & 7 \\
Copulated & 56 \\
Pregnant & 32 \\
Non-pregnant but large preovulatory & \\
follicles or recently ovulated secondary & \\
oocytes & 8 \\
Non-pregnant with degenerating tubal & 3 \\
ova & $13^{*}$ \\
Non-pregnant, no tubal ova found & 63 \\
Total & \\
\hline
\end{tabular}

* Including the following: two anovulatory bats, remainder had CL; one bat with a pathological uterus; at least two tracts lacking pieces of oviduct.

housed with breeding males for $6 \frac{1}{2}$ to 9 months before the efforts to breed from the females were discontinued. At least $57 \%$ of the mated animals became pregnant, while another $14 \%$ had either large preovulatory follicles or recently ovulated secondary oocytes (Tables 1 and 3). Neither preovulatory follicles nor healthy ova could be found in many $(29 \% ; 16$ of 56$)$ of the mated animals. In one case, a recently ruptured follicle was present in one ovary, and abundant cellular débris from the follicle could be noted in the bursa and preampulla of the oviduct. Apparently, the ovum had been lost either naturally to the peritoneal cavity or upon dissection of the tract. Three reproductive tracts, in addition to those from anovulatory animals, were not properly synchronized in histological appearance with their post-coital ages.

\section{Ovarian function}

A single ovum was released at each oestrus, though both ovaries were equally functional (Table 2). A large preovulatory follicle or new CL was in the opposite ovary from the old CL in $94 \%$ of the bats possessing old CL (Table 2). There was no clear association between the reproductive history of the females 
(that is, length of time with the males or since a previous parturition) and the presence or absence of an old CL. Only six females lacked such old CL, and they were killed for histological examination at the following intervals after the first introduction of the males: 17, 31, 130, 133, 164 and 174 days. One of the six females gave birth to a previously conceived infant after being placed with the males in captivity. Ovulation generally occurred within 4 days

Table 2. Number and distribution of preovulatory follicles and corpora lutea in vampire bats which had copulated

\begin{tabular}{l|c}
\hline & No. of animals \\
\hline Anovulatory & 2 \\
One preovulatory Graafian follicle & 1 \\
One corpus luteum & 5 \\
Two corpora lutea: same ovary & 3 \\
Two corpora lutea: opposite ovaries & 40 \\
Preovulatory Graafian follicle and corpus luteum: & 5 \\
$\quad$ opposite ovaries & 56 \\
Total & 1 \\
Preovulatory Graafian follicles-right ovary & 5 \\
Preovulatory Graafian follicles-left ovary & 50 \\
Corpora lutea-right ovary & 46 \\
Corpora lutea-left ovary & \\
\hline
\end{tabular}

of the onset of oestrus, but a preovulatory Graafian follicle was observed as late as Day 5 after the initiation of mating activity (Table 3 ). Germinal vesicle stage primary oocytes (follicle dimension: $490 \times 690 \mu \mathrm{m}$ to $540 \times 715 \mu \mathrm{m}$ ) occurred on Days 1, 2 and 5 (Pl. 1, Figs 1 and 3), while primary oocytes in the anaphase or telophase of the first meiotic division (follicle dimensions: $100 \times 625 \mu \mathrm{m}$ to $725 \times 925 \mu \mathrm{m}$ ) were seen on Days 2 and 3 respectively (Pl. 1, Figs 2 and 4). The cells of the corona radiata and the cumulus oophorus were dispersed in the two Day-3 specimens.

\section{EXPLANATION OF PLATE 1}

Fig. 1. Ovary from a vampire bat (Desmodus rotundus) containing a large preovulatory follicle with a primary oocyte in the germinal vesicle stage (Day 2). HaematoxylinSchiff's reagent (no periodate oxidation). $\times 24$.

FIG. 2. Ovary containing a large preovulatory follicle with a primary oocyte in anaphase of the first meiotic division (Day 2). Masson's trichrome. $\times 24$.

Frg. 3. Higher power view of the oocyte (germinal vesicle stage, Day 2) illustrated in Fig. 1. Haematoxylin-Schiff's reagent (no periodate oxidation). $\times 180$.

Fig. 4. Higher power view of the oocyte (anaphase of the first meiotic division, Day 2) illustrated in Fig. 2. Masson's trichrome. $\times 180$.

FIc. 5. Ovary (Day 1) containing a newly ruptured follicle (RF). A secondary oocyte lies in the bursa ovarii near the fimbria of the oviduct $(F) . I=$ isthmus of the oviduct. Haematoxylin-PAS. $\times 73$.

Fig. 6. Higher power view of the secondary oocyte illustrated in Fig. 5. The oocyte is surrounded by the zona pellucida, the corona radiata, and abundant PAS-positive material (arrow) in the matrix of the cumulus oophorus. Haematoxylin-PAS. $\times 400$. Fig. 7. Pronuclear stage ovum in the oviducal ampulla (Day 2). Masson's trichrome. $\times 400$. 
PLATE

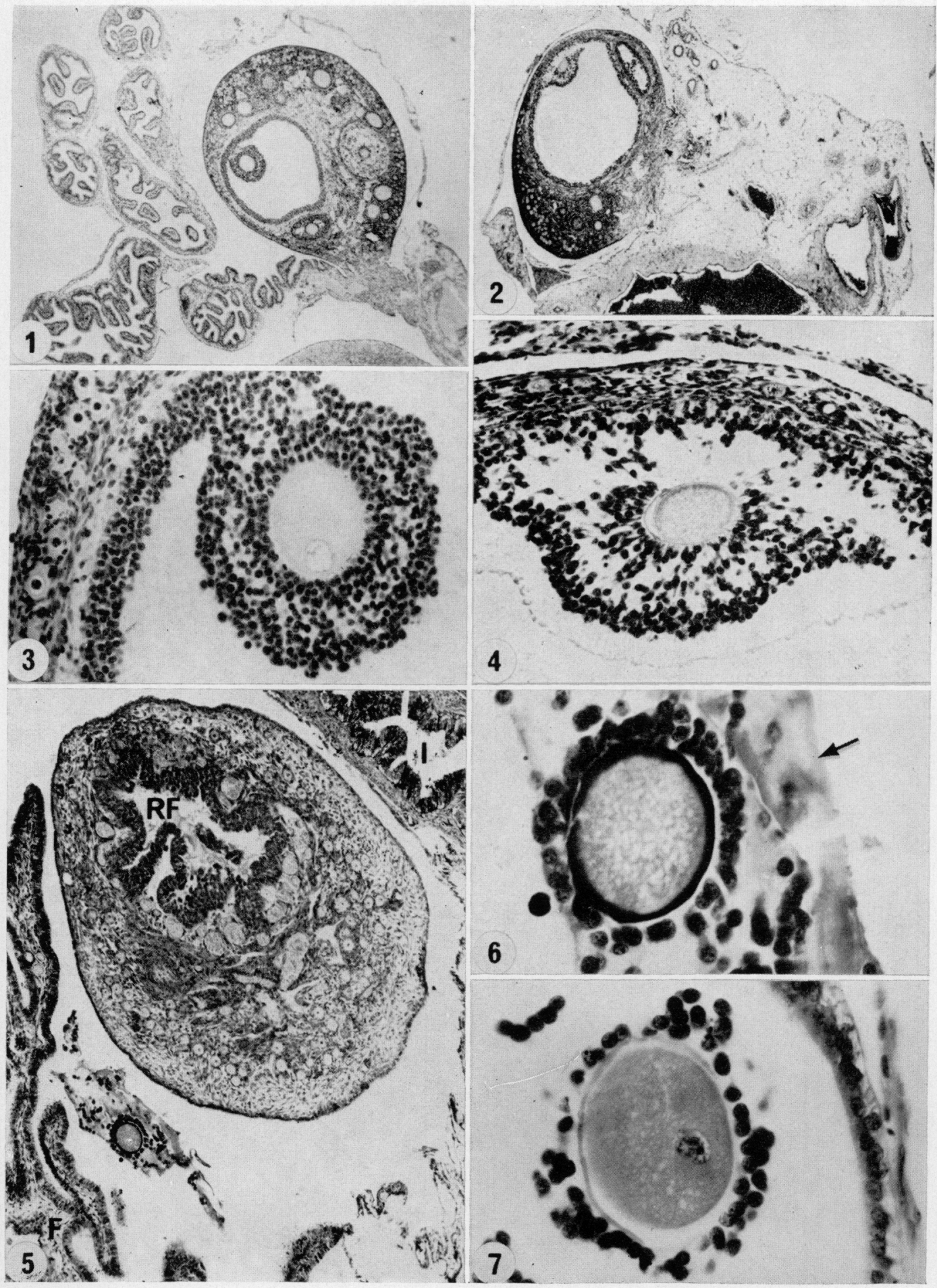




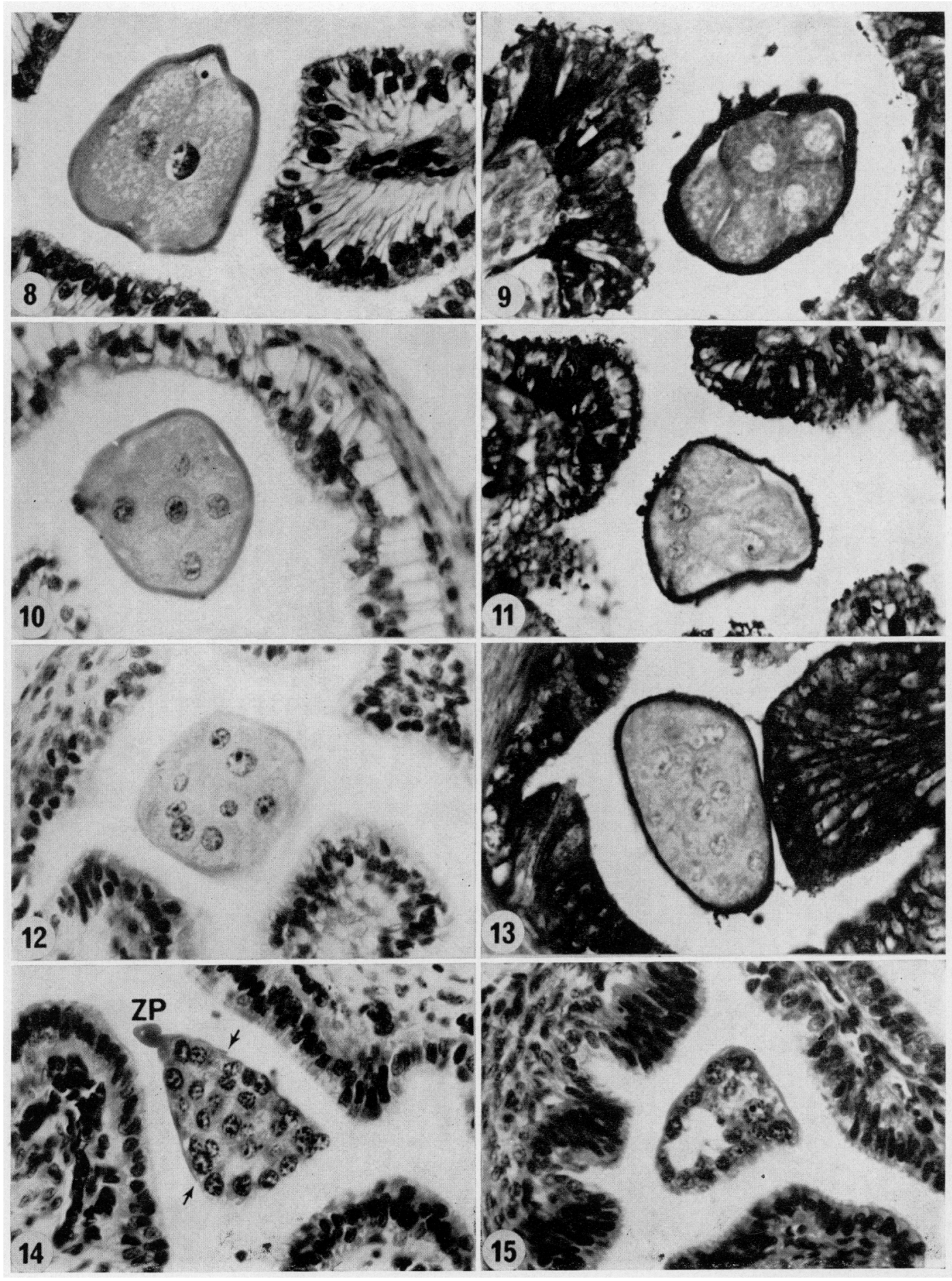


Table 3. Stage of development and location of the ovum in Desmodus rotundus

\begin{tabular}{|c|c|c|c|}
\hline $\begin{array}{l}\text { Day } \\
\text { post coitum }\end{array}$ & $\begin{array}{l}\text { No. of } \\
\text { animals }\end{array}$ & Stage of development & $\begin{array}{l}\text { Location of } \\
\text { ovum }\end{array}$ \\
\hline $\begin{array}{l}1 \\
1 \\
1\end{array}$ & $\begin{array}{l}2 \\
1 \\
1\end{array}$ & $\begin{array}{l}\text { Preovulatory Graafian follicle } \\
\text { Secondary oocyte } \\
\text { Secondary oocyte }\end{array}$ & $\begin{array}{l}\text { Ovary } \\
\text { Ovarian bursa } \\
\text { Ampulla }\end{array}$ \\
\hline $\begin{array}{l}2 \\
2\end{array}$ & $\begin{array}{l}2 \\
2\end{array}$ & $\begin{array}{l}\text { Preovulatory Graafian follicle } \\
\text { Pronuclear stage }\end{array}$ & $\begin{array}{l}\text { Ovary } \\
\text { Ampulla }\end{array}$ \\
\hline $\begin{array}{l}3 \\
3 \\
3\end{array}$ & $\begin{array}{l}1 \\
1 \\
2\end{array}$ & $\begin{array}{l}\text { Preovulatory Graafian follicle } \\
\text { Pronuclear stage } \\
\text { 2-cell }\end{array}$ & $\begin{array}{l}\text { Ovary } \\
\text { Ampulla } \\
\text { Ampulla }\end{array}$ \\
\hline $\begin{array}{l}4 \\
5 \\
5 \\
5 \\
6\end{array}$ & $\begin{array}{l}2 \\
1 \\
1 \\
1 \\
2\end{array}$ & $\begin{array}{l}\text { 2- and 6-cell } \\
\text { Preovulatory Graafian follicle } \\
\text { Pronuclear stage } \\
\text { 7-cell } \\
\text { 4- and 10-cell }\end{array}$ & $\begin{array}{l}\text { Ampulla } \\
\text { Ovary } \\
\text { Ampulla } \\
\text { Ampulla } \\
\text { Ampulla }\end{array}$ \\
\hline $\begin{array}{r}7 \\
8 \\
9 \\
10\end{array}$ & $\begin{array}{l}2 \\
3 \\
1 \\
1 *\end{array}$ & $\begin{array}{l}\text { 2- and 7-cell } \\
4-, 8-\text { and 8-cell } \\
11 \text {-cell } \\
4 \text {-cell }\end{array}$ & $\begin{array}{l}\text { Ampulla } \\
\text { Ampulla } \\
\text { Ampulla } \\
\text { Ampulla }\end{array}$ \\
\hline $\begin{array}{l}11 \\
12 \\
13\end{array}$ & $\begin{array}{l}3 \\
3 \\
2\end{array}$ & $\begin{array}{l}17-, 26-\text { and } 27-\text { cell } \\
18-, 18-\text { and } 24-\text { cell } \\
24-\text { and } 75-\text { cell }\end{array}$ & $\begin{array}{l}\text { Ampulla } \\
\text { Ampulla } \\
\text { Ampulla }\end{array}$ \\
\hline $\begin{array}{l}15 \\
16 \\
16 \\
16\end{array}$ & $\begin{array}{l}2 \\
1 \\
1 \\
1\end{array}$ & $\begin{array}{l}\text { 50-cell and blastocyst }(-Z \mathrm{P}) \dagger \\
\text { 84-cell }(-\mathrm{ZP}) \\
\text { 114-cell }( \pm \mathrm{ZP}) \ddagger \\
\text { Blastocyst }( \pm \mathrm{ZP})\end{array}$ & $\begin{array}{l}\text { Ampulla } \\
\text { Ampulla } \\
\text { Ampulla } \\
\text { Ampulla }\end{array}$ \\
\hline
\end{tabular}

* One pregnant bat (early cleaving ovum), in which sections of the ovum were missing, was not included.

$\dagger$ Zona pellucida was intact unless otherwise noted; $(-Z P)=$ zona pellucida was absent; $( \pm Z P)=$ zona pellucida surrounded part of ovum.

$\$$ Possibly early blastocyst.

\section{EXPLANATION OF PLATE 2}

Fic. 8. Cleavage stage (two cells, Day 4 ) in the oviducal ampulla of a vampire bat. Masson's trichrome. $\times 400$.

Fig. 9. Cleavage stage (ten cells, Day 6 ) in the oviducal ampulla. Haematoxylin-PAS. $\times 400$.

Fig. 10. Cleavage stage (seventeen cells, Day 11) in the oviducal ampulla. Masson's trichrome. $\times 400$.

Fig. 11. Cleavage stage (eighteen cells, Day 12) in the oviducal ampulla. HaematoxylinPAS. $\times 400$.

FiG. 12. Cleavage stage (thirty-seven cells, Day 15) in the oviducal ampulla. Masson's trichrome. $\times \mathbf{4 0 0}$.

Fig. 13. Cleavage stage (seventy-five cells, Day 13) in the oviducal ampulla. Haematoxylin-PAS. $\times 400$.

Frg. 14. Developing embryo (114 cells, Day 16) in the oviducal ampulla. A small space, possibly the early blastocyst cavity, is present in the lower centre of the ovum. The ovum had slipped partly out of its zona pellucida (ZP), the ends of which are indicated by the arrows. Masson's trichrome. $\times 400$.

Fig. 15. Blastocyst (Day 16) partly encased by the zona pellucida in the oviducal ampulla. Masson's trichrome. $\times 400$. 


\section{Fertilization and embryonic development}

Secondary oocytes surrounded by the cumulus oophorus were observed in the ovarian bursa or ampulla on Day 1 (Table 3; Pl. 1, Figs 5 and 6). A third specimen from Day 1 also had a newly ruptured follicle and considerable follicular débris in the bursa, but the ovum could not be found. Eggs with pronuclei were found on Days 2 to 5 ; one observed on Day 2 was still surrounded by the corona radiata (Pl. 1, Fig. 7), but the granulosa cells had disappeared from around the remaining three specimens. Cleavage had commenced in two animals by Day 3, and it subsequently proceeded at a very slow pace (PI. 2, Figs 8 to 13). Two ova had lost the zona pellucida by Days 15 and 16; the discarded zona was evident in the oviduct near one. Two other ova may have been in the process of escaping from their zonae, although it is possible that these zonae were damaged during histological processing (Pl. 2, Figs 14 and 15).

\section{DISCUSSION}

The failure of all eight pregnant animals to mate very shortly after parturition suggests that $D$. rotundus does not exhibit a post-partum oestrus. This conflicts with the previous conclusions of Wimsatt \& Trapido (1952) which were based upon the examination of a single reproductive tract. Relatively few pregnant bats were used in the present study, however, and they may have behaved atypicaily after giving birth. The number or reproductive condition of the males introduced for breeding purposes may also have been a limiting factor.

The presence of old CL in addition to preovulatory follicles or new CL, particularly in the females which had not recently given birth, suggests initially that ovulation in $D$. rotundus is spontaneous as has been reported for the related phyllostomatid bat, Glossophaga soricina (Rasweiler, 1972). Adult male $D$. rotundus, however, were maintained in the animal room before the initiation of efforts to breed from the females, and most of the matings did not occur until the males had been housed together for substantial periods of time. The possibility cannot, therefore, be eliminated that male factors other than mating, or the procedure for taking the vaginal smears, might have induced formation of the older CL. It is also conceivable that these older CL might have persisted from a previous pregnancy, post-partum oestrus, or mating. Gopalakrishna (1969) has reported the prolonged persistence of old CL in one of the pteropodid bats, Rousettus leschenaulti.

The frequency with which alternation of successive ovulations occurs between the two ovaries in $D$. rotundus exceeds that previously noted in $G$. sorcina $(59 \%$; Rasweiler, 1972) and another phyllostomatid bat, Carollia sp. (78\%; Bonilla \& Rasweiler, 1974). The alternation of successive ovulations was reported earlier in two Old World bats, Taphozous longimanus (family Emballonuridae) and $R$. leschenaulti (family Pteropodidae) (Gopalakrishna, 1955, 1969). There is evidence suggesting that the New World families, Desmodontidae and Phyllostomatidae, may have evolved from emballonurid ancestors (Rasweiler, 1974). A tendency towards alternation of ovulations has also been observed in postpartum cows and during shorter menstrual cycles in the rhesus monkey (Saiduddin, Riesen, Tyler \& Casida, 1967; Wallach, Virutamasen \& Wright, 1973), 
and successive CL were always found in opposite ovaries of northern fur seals (Enders, Pearson \& Pearson, 1946). Paradoxically, follicular development in the ewe appears to be enhanced by the presence of a CL in the same ovary (Dufour, Ginther \& Casida, 1972).

In comparing the ovaries from the three species of New World bats, it became apparent that the regressing $\mathrm{CL}$ occupied a much larger proportion of the total ovarian volume in $D$. rotundus than in $G$. soricina, while that of Carollia sp. appeared to be intermediate (J. J. Rasweiler, F. Quintero H. and $H$. de Bonilla, unpublished observations). It had previously been observed that the old CL occupied much of one ovary in some fur seals collected in early summer, i.e. close to the time of ovulation (Enders et al., 1946). Gopalakrishna (1969) also noted that the old CL almost completely fills the ovary in $R$. leschenaulti. The new observations suggest that the alternation phenomenon may occur with a higher frequency in $D$. rotundus because of greater competition between the regressing CL and developing follicles either for a share of the ovarian blood supply or for hormones in the ovarian blood. It is also possible that the old CL might mechanically suppress the growth of new follicles in the some ovary, might produce a substance which acts locally to inhibit the growth of new follicles, or that a substance synthesized preferentially in the oviduct or uterine horn adjacent to the CL might react on the same ovary to inhibit follicular development. It is worth noting that all three New World bat species display unilateral oviducal reactions (Rasweiler, 1972; Quintero \& Rasweiler, 1973; Bonilla \& Rasweiler, 1974), and that Kent (1973) has reported the isolation of a factor from the oviducal contents of hamsters which will inhibit ovarian function. The possibility of some involvement of the uterine horn adjacent to the CL in this postulated inhibition must also be considered in the case of $D$. rotundus, the only one of these three species which possesses a bicornuate rather than a simplex uterus. Localized progestational reactions occur in the endometrium at the cranial end of the horn proximal to the CL in $T$. longimanus and $R$. leschenaulti (Gopalakrishna \& Karim, 1971), but have not been noted during the reproductive period presently under study in $D$. rotundus (J. J. Rasweiler and F. Quintero H., unpublished observations). Several of these theories were suggested previously to explain the alternation of ovulation phenomena observed in fur seals, cows and rhesus monkeys.

It has also been suggested that growth and distortion of the pregnant horn in the fur seal might interfere with circulation through the corresponding ovary, thereby suppressing follicular development in that ovary (Enders $e t$ al., 1946). This theory cannot explain the tendency toward an alternation of successive ovulations in $G$. soricina or the rhesus monkey, since both species possess simplex uteri, and the alternation phenomenon was noted in animals which had not recently given birth (Rasweiler, 1972; Wallach, Virutamasen \& Wright, 1973). Several lines of evidence indicate that this theory also does not apply to the situation seen in $D$. rotundus. As shown in Table 2, there were forty-five bats in which there was a new CL or preovulatory follicle in one ovary and an older CL in the opposite ovary. In twenty-nine of these animals, there was no overt histological evidence of a previous pregnancy. In the other sixteen tracts, one uterine horn was identified as being post-parturient because 
of its greater content of PAS-positive endometrial macrophages and the presence of blood vessels with fibrotic walls (often containing accumulations of PAS-positive fibrinoid) in its myometrium and mesometrium. The preovulatory follicle or new CL was on the same side as the post-parturient horn in twelve of these bats. It is clear that an alternation of successive ovulations had occurred although the older CL had not been adjacent to the pregnant horn.

$D$. rotundus closely resembles $G$. soricina and Carollia sp. in possessing a slow rate of early embryonic development, a protracted tubal journey of the ovum, and loss of the zona pellucida in the oviduct (assuming that the latter is not a processing artifact of the Desmodus material). Another instance of apparent loss of the zona pellucida in the oviduct of $D$. rotundus was reported by Wimsatt (1954). In all three bats, uterine regression associated with involution of old CL ends in menstruation, i.e. endometrial bleeding and desquamation, close to the time of ovulation. When there is no old CL in D. rotundus and Carollia sp., the endometrium is shallow. Regardless of the precise uterine condition at ovulation, most endometrial regeneration in these bats is deferred until afterwards (Rasweiler, 1970, 1972, 1974; Quintero \& Rasweiler, 1973; Bonilla \& Rasweiler, 1974), and it is presumably advantageous for the ovum to be retained in the oviduct during this period.

It has been suggested that loss of the zona pellucida in the oviduct may have developed in the phyllostomatid bats $G$. soricina and Carollia sp. (1) to facilitate early attachment of the blastocyst high in the uterus, (2) because zona loss might be a prerequisite for blastocyst escape from the oviduct, or (3) it may simply reflect the advanced state of development reached by the ovum in the oviduct (Rasweiler, 1972, 1974; Bonilla \& Rasweiler, 1974). Ovum implantation in G. soricina and Carollia sp. occurs shortly after entrance of the blastocyst into a narrow, tubular segment, the intramural uterine cornu, which is interposed between the uterotubal junction and the main cavity of the simplex uterus. This segment is probably homologous with the anterior end of the horn in a bicornuate uterus (Rasweiler, 1974; J. J. Rasweiler and H. de Bonilla, unpublished observations). Although implantation in Desmodus reportedly occurs near the middle of a uterine horn, the horns are quite short and the corpus uteri is long (Wimsatt, 1954). Thus, the site of implantation would still be relatively high in the uterus and possibly homologous to the intramural uterine cornu in the two phyllostomatid bats. Since Wimsatt (1954) studied only two uteri (apparently sectioned transversely) with early implanting blastocysts, the precise anatomical relationship between the site of implantation and the uterotubal junction in $D$. rotundus deserves further examination.

\section{ACKNOWLEDGMENTS}

This work was supported by a grant from the Oficina de Investigaciones, Universidad del Valle and by NIH Grants No. AI-10050 and GM-15289.

\section{REFERENCES}

Björkman, N. H. \& WimsatT, W. A. (1968) The allantoic placenta of the vampire bat (Desmodus rotundus murinus): a reinterpretation of its structure based on electron microscopic observations. Anat. Rec. 162, 83. 
Bonilla, H. DE \& RASWEILER, J. J., IV (1974) Breeding activity, preimplantation development, and oviduct histology of the short-tailed fruit bat, Carollia, in captivity. Anat. Rec. 179, 385.

Constantine, D. G. (1970) Bats in relation to the health, welfare, and economy of man. In Biology of Bats, Vol. II, pp. 319-449. Ed. W. A. Wimsatt. Academic Press, New York.

Correa-Giron, P., Calisher, G. H. \& Baer, G. M. (1972) Epidemic strain of Venezuelan equine encephalomyelitis virus from a vampire bat captured in Oaxaca, Mexico, 1970. Science, N.r. $175,546$.

Dickson, J. M. \& Green, D. G. (1970) The vampire bat (Desmodus rotundus): improved methods of laboratory care and handling. Lab. Anim. 4, 37.

Dufour, J., Ginther, O. J. \& CAsida, L. E. (1972) Intraovarian relationship between corpora lutea and ovarian follicles in ewes. Am. J. vet. Res. 33, 1445.

Enders, R. K., Pearson, O. P. \& Pearson, A. K. (1946) Certain aspects of reproduction in the fur seal. Anat. Rec. 94, 213.

Fleming, T. H., Hooper, E. T. \& Wilson, D. E. (1972) Three Gentral American bat communities: structure, reproductive cycles, and movement patterns. Ecology, 53, 555.

Forman, G. L., BaKer, R. J. \& Gerber, J. D. (1970) Comments on the systematic status of vampire bats (Family Desmodontidae). Syst. Zool. 17, 417.

Gopalakrishna, A. (1955) Observations on the breeding habits and ovarian cycle in the Indian sheath-tailed bat, Taphozous longimanus (Hardwicke). Proc. natn. Inst. Sci. India, B, 21, 29.

Gopalakrishna, A. (1969) Unusual persistence of the corpus luteum in the Indian fruit-bat, Rousettus leschenaulti (Desmaret). Curr. Sci. 38, 388.

Gopalakrishna, A. \& Karim, K. B. (1971) Localized progestational reaction in the uterus of the Indian fruit-bat, Rousettus leschenaulti (Desmaret). Curr. Sci. 40, 490.

Greenhall, A. M. (1965) Notes on behavior of captive vampire bats. Mammalia, 29, 441.

GreENHALl, A. M. (1970) Vampire bat control: a review and proposed research programme for Latin America. Proc. 4th Vertebrate Pest Conference, West Sacramento, California, pp. 41-54. Ed. R. H. Dana. University of California, Davis.

Greenhald, A. M. (1972) The problem of bat rabies, migratory bats, livestock and wildlife. Trans. N. Am. Wildl. \& nat. Resources Conf. 37, 287.

KENT, H. A., JR (1973) A polypeptide from oviductal contents which influences ovarian function. Biol. Reprod. 8, 38.

Lillie, R. D. (1965) Histopathologic Technic and Practical Histochemistry. McGraw-Hill, New York.

MacKenzie, R.B. (1972) The role of silent vertebrate hosts in epidemics of Venezuelan encephalitis. In Venezuelan Encephalitis, pp. 239-243. Pan American Health Organization, Washington, D.C.

Quintero, F. \& Rasweiler, J. J., IV (1973) The reproductive biology of the female vampire bat, Desmodus rotundus. Am. Zool. 13, 1284.

RAsweILER, J. J., IV (1970) The laboratory biology of the long-tongued bat, Glossophaga soricina: maintenance procedures, estivation, the menstrual cycle, histophysiology of the oviduct and intramural implantation Ph.D. thesis, Cornell University, Ithaca, New York.

Rasweiler, J. J., IV (1972) Reproduction in the long-tongued bat, Glossophaga soricina. I. Preimplantation development and histology of the oviduct. F. Reprod. Fert. 31, 249.

RasweiLer, J. J., IV (1974) Reproduction in the long-tongued bat, Glossophaga soricina. II. Implantation and early embryonic development. Am. J. Anat. 139, 1 .

Saiduddin, S., Riesen, J. W., Tyler, W. J. \& Casida, L. E. (1967) Some carry-over effects of pregnancy on post-partum ovarian function in the cow. 7. Dairy Sci. 50, 1846.

Wallach, E. E., Virutamasen, P. \& Wright, K. H. (1973) Menstrual cycle characteristics and side of ovulation in the rhesus monkey. Fert. Steril. 24, 715.

Wimsatt, W. A. (1954) The fetal membranes and placentation of the tropical American vampire bat Desmodus rotundus murinus. Acta anat. 21, 285.

Wimsatt, W. A., Guerriere, A. \& Horst, R. (1973) An improved cage design for maintaining vampires (Desmodus) and other bats for experimental purposes. F. Mammal. 54, 251.

WimsatT, W. A. \& TRAPido, H. (1952) Reproduction and the female reproductive cycle in the tropical American vampire bat, Desmodus rotundus murinus. Am. F. Anat. 91, 415. 